\title{
The Other Modernism
}





\section{The Other Modernism}

F. T. Marinetti's Futurist Fiction of Power

Cinzia Sartini Blum

UNIVERSITY OF CALIFORNIA PRESS

Berkeley Los Angeles London 
University of California Press

Berkeley and Los Angeles, California

University of California Press

London, England

Copyright $(\mathcal{C} 1996$ by The Regents of the University of California

Library of Congress Cataloging-in-Publication Data

Blum, Cinzia Sartini.

The other modernism : F.T. Marinetti's futurist fiction of power / Cinzia Sartini Blum.

p. $\mathrm{cm}$.

Includes bibliographical references and index.

ISBN 0-520-20048-9 (alk. paper). — ISBN 0-520-20049-7 (pbk. : alk. paper)

1. Marinetti, Filippo Tommaso, $1876-1944$ - Criticism and interpretation. 2. Futurism (Literary movement) - Italy. I. Title. $\mathrm{PQ}_{4} 829 . \mathrm{A}_{7} 6 \mathrm{Z}_{57} \quad 1996$ $88^{\prime} \cdot 91209$-dc2o

$96-3604$

CIP

\author{
Printed in the United States of America \\ 987654321
}

The paper used in this publication meets the minimum requirements of American National Standard for Information Sciences-Permanence of Paper for Printed Library Materials, ANSI Z $39 \cdot 48-198_{4}$ 